\title{
Dét, \\ som kommer til syne, i rummene mellem forskningsfelter Interview med Niels Nyegaard
}

\author{
Af Marie-Louise Holm
}

\section{INDLEDNING}

Den 28. september 2018 forsvarede Niels Nyegaard sin ph.d.-afhandling med titlen Perverse forbrydere og gode borgere: Homoseksualitet, heteronormativitet og medborgerskab $i$ Københavns offentlighed, 1906-11 på Institut for Kultur og Samfund ved Aarhus Universitet. I sin afhandling undersøger Nyegaard, hvordan Københavns offentlighed beskæftigede sig med en række homoseksuelle skandalesager i 1906-11. Han afdækker i den forbindelse, hvordan forskellige hovedstadsdagblade og småskrifter konstruerede en særlig homoseksuel figur i relation til det moderne danske medborgerskab, og belyser, hvilken betydning disse konstruktioner fik for medborgerskabets historiske kobling til heteroseksualitet. Afhandlingen viser, at årene 1906-11 var en tid, hvor adskillige stemmer i Københavns offentlighed gestaltede det moderne danske medborgerskab som et heteroseksuelt medborgerskab ved at udgrænse den homoseksuelle figur som en ikke-medborger. I det følgende mail-interview har Marie-Louise Holm spurgt Niels Nyegaard om hans syn på ældre og nyere perspektiver og tilgange i køns- og seksualitetsforskning inden for historiefeltet og om, hvordan historisk forskning kan have betydning i nutiden og for fremtiden. 


\section{AT UDBYGGE DEKONSTRUKTIVISTISKE OG QUEER PERSPEKTIVER \\ PÅ MEDBORGERSKAB}

Marie-Louise Holm: Hvilke former for tidligere historiske tilgange til og forskningsprojekter om køn og seksualitet har inspireret dig i forhold til at udvikle din egen forskningstilgang?

Niels Nyegaard: Min forskning tager afsæt i flere historiske tilgange til studiet af $\mathrm{k} ø \mathrm{n}$ og seksualitet - både danske og internationale. Hvis jeg skal pege på nogle konkrete forskningsprojekter, som har haft stor betydning for mit arbejde, er der især fire publikationer, som jeg vil fremhæve.

Den første publikation er Wilhelm von Rosens doktordisputats Månens kulør: Studier $i$ dansk bøssehistorie 1628-1912 fra 1993. I disputatsen brugte von Rosen et foucauldiansk perspektiv til at undersøge det danske samfunds skiftende konstruktioner af sex og erotik imellem mænd fra tidligmoderne tid og frem til den moderne xra. Hans undersøgelse viste, at den homoseksuelle figur er en historisk konstruktion, der først kom til syne i Danmark omkring år 1900 (von Rosen 1993, 655ff). Denne pointe har været vigtig for min forskning, fordi den har fået mig til at se seksualitet - både homo- og heteroseksualitet - som en historisk installation, der specifikt hører hjemme i moderniteten. Med dette udgangspunkt har jeg været interesseret $\mathrm{i}$ at undersøge, hvorvidt, og eventuelt hvordan, århundredskiftets voldsomme stigmatisering af en fremvoksende homoseksuel figur var med til at knytte det moderne danske medborgerskab til heteroseksualitet. Herved har jeg forsøgt at bygge videre på von Rosens arbejde ved at undersøge den homoseksuelle figurs rolle i produktionen af heteroseksualitet som den normale medborgerseksualitet.

I min afdækning af denne heteroseksuelle medborgerskabsproduktion har Karin Lützens bog Byen tammes: Kernefamilie, sociale reformer og velgorenhed $i$ 1800-tallets København fra 1998 også været en central inspirationskilde. I bogen undersøgte Lützen, hvordan borgerskabets kernefamilieideal kom til syne i 1800-tallet, og hvordan dette normkompleks gradvist spredte sig til resten af samfundet, blandt andet via borgerskabets private filantropi. Jeg kender ikke Lützens og andres opfattelse, men for mig står denne undersøgelse som noget af det mest queer historieforskning, der er lavet i Danmark, fordi den sætter analytisk fokus på kernefamiliens historiske konstruktion som det normale. I min ph.d.-afhandling har jeg forsøgt at videreføre denne form for queer analyse ved at undersøge den fremvoksende homoseksuelle figurs betydning for det moderne danske medborgerskabs historiske heteroseksualisering omkring år 1900. På den måde har jeg bestræbt mig på at supplere Lützens dekonstruktion af borgerskabets heteronormative kernefamilieideal med en queer dekonstruktion af heteroseksualiteten som den normale medborgerseksualitet.

I denne dekonstruktive bestræbelse har jeg yderligere været inspireret af min vejleder Nina Koefoeds artikel Demokrati og medborgerskab: Sociale og kønspolitiske strategier $i$ debatten om den almindelige kommunale valgret $i$ 1886-1908 fra 2008. Jeg har især været inspireret af det feministiske intersektionalitetsperspektiv, som Koefoed her anvendte til at betone den flerhed af sociale kategorier, der indgik i danske medborgerskabsdebatter omkring år 1900. Mere specifikt omhandlede debatterne ikke kun køn, det vil sige kvinders manglende adgang til fuldt medborgerskab. Ifølge Koefoed handlede de også om civilstand $\mathrm{og}$ social klasse, fordi flere mænd var ekskluderede fra medborgerskabets fulde rettigheder på grund af manglende husbondstatus eller fattigdom (Koefoed 2008, 253-55). I min ph.d.-afhandling har jeg arbejdet videre med denne intersektionelle tilgang til studiet af det moderne danske medborgerskab ved at undersøge, hvordan flere socia- 
le kategorier indgik i århundredskiftets konstruktioner af den inkluderede danske medborger og den ekskluderede ikke-medborger. Jeg har især bygget videre på Koefoeds pointe ved at undersøge, hvordan seksualitet omkring år 1900 kom til at supplere køn, civilstand og social klasse som et centralt parameter i samfundets medborgerskabsdefinitioner, så den danske medborger blev defineret som et heteroseksuelt subjekt.

Til sidst vil jeg nævne amerikanske Margot Canadays bog The Straight State: Sexuality and Citizenship in Twentieth-century America fra 2009, som jeg også har trukket på i min forskning. I bogen sporede Canaday det amerikanske medborgerskabs historiske heteroseksualisering tilbage til 1900-tallets begyndelse, hvor de amerikanske immigrationsmyndigheder rutinemæssigt afviste homoseksuelle indvandrere, når de ankom til New York. Herved kom den amerikanske medborger ifølge Canaday til syne som et heteroseksuelt subjekt igennem den performative udgrænsning af den homoseksuelle figur som en ikke-medborger (Canaday 2009, 19ff). Pointen om, at den historiske kobling imellem medborgerskab og heteroseksualitet kan forstås som en afledt effekt af den homoseksuelle figurs andetgørelse som en social outsider, har været vigtig for min forskning. Det er netop denne mekanisme, jeg har ønsket at inddrage $\mathrm{i}$ en dansk kontekst og undersøge i mit studie af Københavns offentlighed i 1906-11.

\section{RUMMENE MELLEM FORSKNINGSFELTER}

Marie-Lonise Holm: Hvad ser du selv som din ph.d.-afhandlings vigtigste bidrag til den eksisterende forskning?

Niels Nyegaard: Jeg tror, min ph.d.-afhandlings vigtigste bidrag er, at den etablerer en særlig form for queer vidensproduktion, der udspringer af min undersøgelses placering i rummene imellem allerede eksiste- rende forskningsfelter. Med afsæt i Judith Butlers opfordring til forskere om ikke at antage et afgrænset og passende genstandsfelt' for deres studier af moderne seksualitet (Butler 1994), har jeg forsøgt at nedbryde etablerede faglige afgrænsninger og undersøge seksualitet i relation til andre sociale kategorier og forskningsfelter, især medborgerskab. På den baggrund kan min ph.d.-afhandling ikke entydigt defineres som enten seksualitetshistorie med fokus på den homoseksuelle figurs tilsynekomst i Danmark omkring år 1900 eller som medborgerskabshistorie med fokus på medborgerskabets modernisering i samme periode. Derimod gør afhandlingen noget nyt, idet den placerer sig midt imellem disse to forskningsfelter og binder dem sammen ved at afdække, hvordan den fremvoksende homoseksuelle figur var med til at producere den danske medborger som et heteroseksuelt subjekt i tiden omkring år 1900.

\section{HISTORIEFORSKNING SATTER NUTIDIGE SPØRGSMÅL I PERSPEKTIV}

Marie-Lonise Holm: Historie som tidslighed, situation og fortælleform er netop væsentlig at anvende $\mathrm{i}$ forhold til $\mathrm{k} ø \mathrm{n}$ og seksualitet, fordi dette kan give nye perspektiver på dét, som tages for givet i nutiden. Samtidig bliver historien meningsfuld ud fra og peger på, hvad der ses som vigtigt i en nutidig kontekst. Hvordan ser du dit ph.d.-projekt i forhold til dette perspektiv?

Niels Nyegaard: Der er ingen tvivl om, at den køns- og seksualitetshistoriske forskning er vigtig, fordi den kan vise den tidslighed og historiske foranderlighed, der kendetegner nutidens forståelser af køn og seksualitet. Historiske studier gør os klogere på vores samtid ved at synliggøre, at tingene ikke altid har været sådan, som de er i dag - at køn og seksualitet er historiske og foranderlige konstruktioner. Denne pointe har spillet en central rolle i mit arbejde, 
hvor jeg især har været inspireret af Foucaults tanker om genealogien som en historisk undersøgelse, der: "fremviser heterogeniteten i det, man forestillede sig var i overensstemmelse med sig selv" (Foucault 2001, 63). Med udgangspunkt i denne foucauldianske tanke kan man sige, at det er nutidens ofte uantastede forestilling om en særlig uforanderlig, naturlig og oprindelig overensstemmelse imellem medborgerskab og heteroseksualitet, som jeg på genealogisk vis har dekonstrueret i min ph.d.-afhandling. Min undersøgelse viser, at denne sammenkobling ikke er universel eller ahistorisk, fordi den først kom til syne i Danmark i den moderne æra.

Denne dekonstruktion ser jeg desuden som et historiefagligt bidrag til de debatter, der i de senere år har omgivet den homoseksuelle figurs igangværende overgang til en inkluderet dansk medborger. Som blandt andre Michael Nebeling Petersen har påpeget, har de seneste 20-30 år været kendetegnet ved, at den homoseksuelle figur gradvist har mistet sit traditionelle stigma af sygdom, degeneration og død. I dag fremstår figuren mere som en inkluderet medborger med ret til ægteskab, familieskab, reproduktion og liv (Petersen 2012). Denne udvikling har tiltrukket sig stor interesse blandt flere forskere, der eksempelvis har diskuteret udviklingens historiske forudsætninger, dens heteronormative præmisser og dens forhold til det såkaldte danske frisind (fx Bech 1992; 2002; Lützen 1998b; Petersen 2012; Stormhøj 2007; 2015; Søland 1998).

Jeg ser min forskning som et faghistorisk bidrag til disse diskussioner, da jeg undersøger, hvordan det moderne danske medborgerskab historisk set er blevet konstitueret som heteroseksuelt ved at ekskludere den homoseksuelle figur. Ved at undersøge denne historiske proces har jeg forsøgt at kvalificere nutidens diskussioner af, hvordan figuren i de seneste årtier er blevet inkluderet $\mathrm{i}$ et allerede heteroseksuelt medborgerskab.

\section{Forskellige TILGANGE GIVER} NY VIDEN

Marie-Louise Holm: Hvilken forskel mener du, at det kan gøre at anvende nye teoretiske og metodiske tilgange i historisk forskning om køn og seksualitet i forhold til vidensproduktion og aktuelle diskurser om køn og seksualitet?

Niels Nyegaard: Jeg tror, at det kan gøre en stor forskel. For mig at se bidrager historisk forskning ikke kun til vidensproduktion og aktuelle køns- og seksualitetsdiskurser ved at undersøge nye empiriske genstandsfelter. Historisk forskning kan også yde vigtige bidrag ved at anvende nye teoretiske og metodiske tilgange. Inden for mit eget forskningsfelt er et godt eksempel på denne pointe den flerhed af teoretiske tilgange, som forskellige historikere har brugt i deres studier af det samme empiriske genstandsfelt, nemlig Københavns dagblade og disses beskxftigelse med de homoseksuelle skandalesager i 1906-11. Københavns dagblade blev først studeret af Wilhelm von Rosen, der i Månens kulør brugte et foucauldiansk perspektiv til at se deres omtale af de homoseksuelle skandalesager som en begivenhed, der var med til at introducere en ny homoseksuel figur i det moderne Danmark (von Rosen 1993, 719ff). For nylig har Cecilie Bønnelycke kastet nyt lys over dagbladenes homoseksualitetskonstruktioner ved at undersøge dem i et følelsesteoretisk perspektiv (Bønnelycke 2016; 2018). Bønnelyckes forskning viser, at hovedstadsdagbladenes udsagn om de homoseksuelle skandalesager også havde en affektiv dimension, der knyttede den fremvoksende homoseksuelle figur til følelser som væmmelse, forargelse, frygt og medlidenhed. Endelig har jeg i min ph.d.-afhandling undersøgt dagbladenes omtale af de homoseksuelle skandalesager i et queer medborgerskabsperspektiv. I forlængelse af dette perspektiv har jeg påvist, at dagbladenes omtale af den nye homoseksuelle figur også var med til at de- 
finere den moderne danske medborger som et heteroseksuelt subjekt. Disse eksempler viser i min optik, at den metodiske og teoretiske tilgang har stor betydning for den viden, vi producerer som historikere. På den baggrund er jeg overbevist om, at nye forskningsbidrag kan opstå igennem anvendelsen af nye teoretiske og metodiske tilgange.

\section{ET VIDTSPÆNDENDE FORSKNINGSFELT UNDER PRES}

Marie-Louise Holm: Ud over hvad du har arbejdet med i din egen forskning, hvad synes du så, som nyuddannet forsker i kønsog seksualitetshistorie, er de væsentligste emner, problematikker, etiske og metodiske spørgsmål, som træder frem i historiske tilgange til køn og seksualitet i forskningen i dag?

Niels Nyegaard: Det er et godt spørgsmål. Heldigvis er den historiske køns- og seksualitetsforskning et felt, som spænder relativt vidt, hvis man ser på de perioder, emner, empiriske genstandsfelter, teorier og metoder, som i dag konstituerer feltet. På den baggrund tror jeg, det kan være svært at udpege ét spørgsmål eller ét emne som den vigtigste forskningsmæssige problemstilling i forskningsfeltet samlet set. Måske er det heller ikke særlig ønskværdigt at udpege en sådan tematik, fordi man herved risikerer at udstikke en normativ og potentielt ekskluderende forskningsagenda, der kan udtynde de muligheder for ny og heterogen vidensproduktion, som ligger gemt i det eksisterende felt.

Hvis jeg alligevel skal pege på én ting, der for mig står som en samlende udfordring for den historiske køns- og seksualitetsforskning, så er det de institutionelle og økonomiske rammer, der udgør en forudsætning for forskningens fortsatte eksistens. Der er ingen tvivl om, at vi i disse år ser en udvikling kendetegnet ved hård kamp om få forskningsmidler og ringere muligheder for fastansættelse på eksempelvis landets universiteter. I denne situation er det vigtigt, at vi som køns- og seksualitetshistorikere står sammen om at fremhæve vigtigheden af vores forskning, og at vi sammen kxmper for at sikre de institutionelle rammer, forskningsmidler, netværk, samarbejder, etc., der kan sikre vores forskning i fremtiden. Meget er allerede sket, eksempelvis med stiftelsen af Konshistorisk Netverk $i$ Danmark. Dog er der ingen tvivl om, at der er tale om udfordringer, som vi også i de kommende år kommer til at forholde os til som et samlet forskningsfelt.

Vejleder på Niels Nyegaards ph.d.-afhandling var lektor Nina Koefoed, Aarhus Universitet. Bedømmelsesudvalget ved forsvaret bestod af professor MSO Rikke Andreassen, RUC, professor Jens Rydström, Lunds Universitet, samt lektor Claus Møller Jørgensen, Aarhus Universitet. Interesserede kan rekvirere et eksemplar af afhandlingen i pdf-format ved at skrive til Niels Nyegaard på mail-adressen: nielsnyegaard@hotmail.com.

\section{LITTERATUR}

- Bech, H. 1992. Report from a Rotten State:

'Marriage' and 'Homosexuality' in 'Denmark'. I: Plummer, K. red. Modern Homosexualities: Fragments of Lesbian and Gay Experience. New York: Routledge, 137-147.

- Bech, H. 2002. Det onde i Danmark. Dansk Sociologi. 13(3), 49-74.

DOI:10.22439/dansoc.v13i3.444

- Butler, J. 1994. Against proper Objects: Introduction. I: differences: A Journal of Feminist Cultural Studies. 6(2-3), 1-26.

. Bønnelycke, C. 2016. "Storbyens allerlaveste kryb": Den københavnske sædelighedsskandale 
1906-07. Historiske meddelelser om København 2016, 156-185.

. Bønnelycke, C. 2018. "De uappetitligste fyre": Om følelsernes rolle i dækningen af sædeligheds skandalen 1906-07". temp-tidsskrift for historie. 16, 81-99.

- Canaday, M. 2009. The Straight State: Sexuality and Citizenship in Twentieth-century America. Princeton: Princeton University Press.

- Foucault, M. 2001. Nietzsche - Genealogien, historien. I: Foucault, M. Talens forfatning. København: Hans Reitzels Forlag, 57-82.

- Koefoed, N. 2008. Demokrati og medborgerskab: Sociale og kønspolitiske strategier i debatten om den almindelige kommunale valgret 1886 1908. Fortid og Nutid. 4, 251-278.

- Lützen, K. 1998a. Byen temmes: Kernefamilie, sociale reformer og velgørenhed i 1800-tallets København. København: Hans Reitzels Forlag.

- Lützen, K. 1998b: Gay and Lesbian Politics: Assimilation or Subversion: A Danish Perspective.
Journal of Homosexuality. 35(3-4), 233-243.

DOI:10.1300/J082v35n03_10

- Petersen, M. N. 2012. Somewhere over the rainbow: Biopolitiske rekonfigurationer af den homoseksuelle figur. Ph.d.-afhandling, København: Københavns Universitet.

- von Rosen, W. 1993. Månens kulør: Studier $i$ dansk bøssehistorie 1628-1912. København: Rhodos.

. Stormhøj, C. 2007. Homoseksuelles medborgerskab i et retfærdighedsperspektiv. Kvinder, Køn \& Forskning. 16(4), 33-41.

DOI:10.7146/kkf.v0i4.27918

. Stormhøj, C. 2015. Crippling Sexual Justice. NORA: Nordic Journal of Feminist and Gender Research. 23(2), 79-92.

DOI:10.1080/08038740.2014.993423

- Søland, B. 1998. A Queer Nation? The Passage of the Gay and Lesbian Partnership Legislation in Denmark 1989. Social Politics. 5(1), 48-69. DOI:10.1093/sp/5.1.48 